\title{
Relevance of Stakeholders in Policy Implementation
}

\author{
Dr. Ibrahim Yaro (Corresponding author) \\ Dept. of Public Administration, Faculty of Management Sciences, Usmanu Danfodiyo \\ University \\ P.M.B. 2346, Sokoto, Nigeria \\ Tel: +234-8065672066_E-mail: yaro048@yahoo.com \\ Dr. Rozita Arshad \\ Dept. of Public Management, School of Government, Universiti Utara Malaysia \\ Tel: +60-134-899-696 E-mail: roz@uum.edu.my \\ Associate Prof. Dr. Dani Salleh \\ Dept. of Planning and Property Development, School of Government, Universiti Utara \\ Malaysia \\ Tel: +60-135-225-586 E-mail: $\underline{\text { dani@uum.edu.my }}$
}

Received: January 20, 2017 Accepted: February 2, 2017 Published: February 13, 2017 doi:10.5296/jpmr.v3i1.10632ＵRL: http://dx.doi.org/10.5296/jpmr.v3i1.10632

\begin{abstract}
The purpose of this study is to examine the relevance of stakeholders in education policy implementation. This become necessary for the fact that despite efforts of most countries in contemporary world of not only trying to ensure that quality education is received, but of making education accessible to all, the aim has not been adequately achieved due to ineffective implementation of the education policies and lack of relevant stakeholder's involvement as the government alone cannot shoulder the responsibility of education provision. Using qualitative research approach, 15 respondents were purposively interviewed and the result analyzed using Nvivo software. The findings indicated that education stakeholders have significant role to play in policy implementation which is categorized into two themes (i.e. total commitment and supporting the school system). It is therefore, recommended that stakeholders should be allowed full participation in education provision;
\end{abstract}


government should as well provide sound measures of effective implementation so that collaboratively quality education could be ensured.

Keywords: Education Stakeholders, Policy Implementation, Quality Education

\section{Introduction.}

The relevance of stakeholders in the implementation of policies in every sector education sector inclusive cannot be over-emphasized. For this reason, most governments in different parts world are constantly engaging stakeholders in the implementation of government policies as this facilitates and improve the workings of government (Geurtz \& van 2010). For instance, studies such as Ayeni (2014), Kufi (2013), Takyi, et al. (2013), established that the education provision is a collective task which required contribution from relevant stakeholders.

Furthermore, studies such as Clase and Van (2007), Mualuko et al. (2009) James et al. (2010) Lin (2010) Charles and Sunday (2014) and Yaro et al. (2015) indicated that stakeholders participation in education related issues has great impact in educational policy implementation towards attaining quality education. For instance they play the role of ensuring accountability in education (Mandina \& Chiheve, 2013), have significant impact in education financing (Oseni, 2012), plays significant roles in ensuring quality education through promoting effectiveness and efficiency of procedures for quality improvement (Brussels, 2011), improving quality of decision making (Mualuko et al. 2009), improving the quality of educational system (Kamba, 2010) and above all and have impact in the design and execution of government education policies (Chinelo, 2011; Odufowokan, 2011). In Nigerian context, the 2013 revised edition of the national education policy stated that in order to ensure rapid implementation of education policies for quality education, relevant stakeholders should be involved. This is due to the fact that stakeholders in education sector are individuals who are concerned with education (Adebayo, 2013), and as such they play many roles of ensuring that the school system accomplish its specified goals and objectives that are directed at ensuring quality education. However, despite these enormous roles, the quality of graduates produced esspecially in public secondary schools are nothing to take home with due to ineffective implementation of the education policies (Bateye \& Ogunyemi, 2015; Innocent, 2013) in addition to non-involvent of relevant stakeholders in education provision (Olatunji, 2012; Olaleye, 2013; Ayeni, 2012). This condition led to failure in managing or administering of most of the schools (Azeem, 2010), thereby hindering accomplishing quality education. The objective of this paper is therefore, to examine the relevance of stakeholders in education policy implementation towards ensuring quality educational output.

\section{Literature Review.}

\subsection{Education Stakeholders}

Stakeholders are individuals or group of individuals that are directly affected or can directly influence achieving the objectives of an organization (Freeman, 1984). This notwithstanding Crosby (1992), Mason and Mitroff (1981), and Walt (1994) noted that stakeholders are regarded as only those individuals that have impact on the outcome of a particular policy. For 
this reason, Brugha and Varvasovszky (2000) opined that stakeholders refer to such individuals or groups with conferred interest that can likely influence the policies of an organization. As individuals with remarkable interest in the education sector (Adebayo, 2013), education stakeholders has as a major objective of making sure that quality graduates that can think reasonably and also those with the capability of moving the society forward are produced in schools (Schlechty, 2001). They are particularly concerned about the well-being and improvement of a school including student's achievements. These category of individuals are known to consists of head-teachers, teachers, students, parents, parents teachers association, school management committee, school board members, community members, elected officials, non-governmental organizations (NGO's) and board of governors among others (Halle et al., 2011). They can thus be identified as internal or external stakeholders (Stefl \& Tucker, 1994; Paine \& McCann, 2009). The internal stakeholders work in the school whose responsibility is that of handling school's activities. They comprise of school's staff, district officials and school's board members. Whereas the external stakeholders do not straight away influence educational outcomes but have keen interest in the outcomes; buy and large, the external stakeholders do not work in the school and they include members of the community including parents, non-governmental organizations, interest groups and members of the media (Paine \& McCann, 2009).

\subsection{Policy Implementation}

Policy implementation is described as the process of interaction between the setting of goals and the activities and actions that followed towards achieving those goals (Pressman \& Wildavsky, 1973). Implementation therefore occurred when the policy decisions reached by the government are put into effect, as specified in the documented priorities that are incorporated either in a statute or in the form of significant executive orders or court verdicts (Mazmanian \& Sabatier, 1983). Implementation also comprised activities such as applying significant rules and putting into effect appropriate laws for the purpose of making public services available to the people (Brooks, 1998). Kraft and Furlong (2007) and Ajaegby and Eze (2010) noted that implementation has to do with execution of government policies. This is why implementation is often regarded as undertaking a task to achieve some targeted goals (Paudel, 2009). It involves all the techniques and efforts of realizing the policies decided upon by the government in order to accomplish the desired outcome as stipulated in the policy guidelines. Thus, policy implementation is the routine governmental processes of putting the government's targeted goals into action which is usually done by government agencies or its officials in accordance with the stipulation of the law. Effective implementation of education policies is therefore, very vital as it leads to the accomplishment of the final educational output (i.e. attaining quality education).

\section{Methodology}

This research used qualitative research approach in obtaining and analyzing the data. By using qualitative approach, there is tendency of getting valid, genuine and reliable data especially in instances where there is no fear on the part of the participants of the consequences of the information given (Miles \& Hurberman, 1994). However, in order to get 
the desired information, the research participants were purposively selected, for the fact that relevant information can be obtained from them out of their experience of the phenomenon under investigation (Creswell, 2007). Based on this, a total of fifteen (15) research participants were selected and interviewed as shown in Table 1. The selection of the research participants does not contradict the sampling requirement in a qualitative study as suggested by Adler and Adler (2011) who proposed a total of twelve (12) interviews in a qualitative study. However, due protocols of ensuring quality interview as suggested by McNamara (2009) were applied, and the research participants were asked the question: "what is the relevance of stakeholders in education policy implementation?"

The interview was first of all transcribed on completion of the interview session after which thematic analysis was used to analyze the data (Denscombe, 2003; Gibson, 2006; McNamara, 2009). The sorted data was later categorized into themes and sub-themes using the Open, axial and selective coding (Strauss and Corbin, 1990). The process enabled easy categorizing and comparison of the sorted data in order to identify the group within which each category belongs. For easy identification, the research participants were coded as R1, R2, R3 up to R15 symbolizing research participants 1, research participant 2 etc.

Table 1. Research Participants

\begin{tabular}{ccc}
\hline No. & Research Participants & Total Number \\
\hline 1 & Policy makers and implementers & 6 \\
2 & School administrators & 5 \\
3 & Parents & 4 \\
& Total & 15 \\
\hline
\end{tabular}

\section{Analysis and Discussion}

The information obtained from the research participants indicated that stakeholders have great relevance and important roles to play in the implementation of education policies. These roles are categorized into two themes namely: commitment by the stakeholders and supporting the school. However, each of the themes has sub-themes. This clearly indicated that to ensure progress and perfectly implements policies, the role of stakeholders should not be ignored. This is why Torenvlied and Akkerman (2004) stressed the significance of the interaction between public and private organization in the implementation of policies as engaging actors that are not within the government circle is now given much emphasis in the new governance approach to public administration and the new public management (Peter, 2014). This is also in line with the provision of the 2013 revised edition of the Nigerian national policy on education which guaranteed stakeholders support and participation towards adequate education provision for the purpose of removing or reducing overlaps, and to sustain and achieve synergy.

\subsection{Commitment by Stakeholders}

From the research findings, it was identified that total commitment of stakeholders in education provision which is the first theme of the research is of paramount importance as it 
leads to successful implementation of school's policies that are designed to ensure quality academic outputs or quality education. The total commitment of stakeholders as displayed in figure 1 has oversight functions by the legislative members, proper implementation by the government and school administrators, collaborative efforts, attending PTA meetings as well as provision of funds as sub-themes.

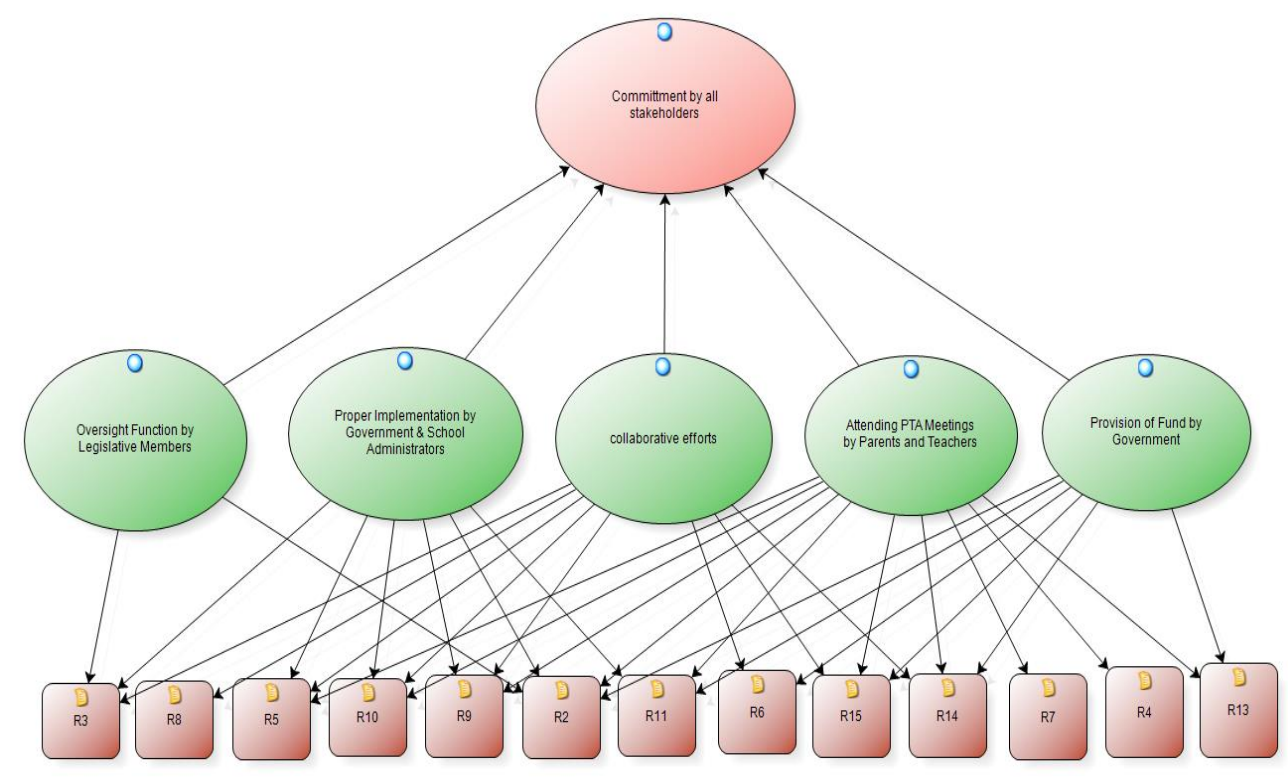

Figure 1. Commitment by stakeholders

\subsubsection{Oversight functions}

On the issue of oversight functions, the research participants have this to say:

- "As part of our functions, after passing the budget we also perform oversight functions as provided in the constitution of the Federal Republic of Nigeria. The oversight function allow us to interact with teachers and other heads of educational institutions in order to discuss educational challenges which we most often report to the legislature in form of a report containing our recommendations. This is deliberated on the floor of the legislature in the committee of the whole House for deliberation. After deliberations, if the report is accepted by the legislature it will then be passed to the executive arm for further action".

- "We also perform the function of supervising the implementation of government policies. In addition to this, we perform enlightment campaigns and hold town hall meetings with people at the grassroots particularly the stakeholders that are responsible for formulating and implementing the policies as well as members of the community whom the policies are meant to benefit".

One of the relevance of stakeholders in education policy implementation is through oversight functions. This entail the constitutional obligation bestowed on the legislative members to supervise government's activities in ministries and parastatals. This enables the legislative members to know whether the budget appropriated to government's agencies are properly used or otherwise; this also aid in checking the excesses of those responsible for 
implementation, so as to prevent them from engaging in corrupt practices that will eventually affect proper implementation and consequently affects the quality education.

\subsubsection{Proper Implementation:}

On this note, the stakeholders interviewed lamented that:

- "We should all try to ensure the stability as well as full implementation of the policies. As a matter of utmost importance the policies should be fully implemented and not thrown out at the initial stages of its take off. This can be ensured when there is strong bureaucratic capacity".

- "To fully implement education policies, the relationship between teachers and school administrators should be strengthened. It is the duty of the school administrators to remind the teachers of their duties and responsibilities. This is what I did as a school administrator and most of the teachers support the idea. This enabled me to easily identify any lapse with a view to rectify the challenges".

- "It is my duty as a teacher to teach students according to the stipulation of the curriculum and this is what I do. When a teacher teaches he is directly implementing the education policy as such teachers should sit up to their responsibilities".

This is inevitable as one of the relevance of stakeholders in education policy implementation especially the government and the school administrators is to ensure that the policies are properly implemented. Effective implementation by these stakeholders as identified by the research participants enabled attaining quality education. Dorathy (2009) and Audu, et al. (2013) found out that the low level of education in most secondary schools of Nigeria emanated from ineffective implementation including acting contrary to the dictates of the curriculum. The findings showed that in order to properly implement the policies, government should ensure that adequate instructional materials are provided. Similarly, the school administrators should ensure that they give teachers accurate information so as to effectively teach in accordance to the stipulation of the curriculum.

\subsubsection{Collective efforts:}

On collective efforts almost all of them agreed that education provision is a collective responsibility as stated below:

- "Collaborative efforts between stakeholders especially the government, parents, teachers, and NGO's etc. is essential. It is imperative for the stakeholders to sincerely join hands and contributes towards successful implementation so that quality education could be attained".

- "Presently, education provision is regarded as the responsibility of all, which required collaborative efforts by the stakeholders especially the government, parents, teachers, members of the community and wealthy individuals in the society for the purpose of effective implementation of the education policies".

- "Practically, it is not easy for the government to shoulder the responsibility of education provision alone. There is therefore, the need for the participation and support of members of 
the community, the wealthy individuals, the parents and everyone to put more efforts and provide adequate resources for effective teaching and learning to take place. In other words, all relevant stakeholders should actively collaborate towards making this s reality".

Education provision as identified by the research participants is one of the significant roles of education stakeholders in policy implementation as it enhances efficiency and effectiveness of service delivery. The research participants expressed the need for the stakeholders especially the parents to collaborate with the teachers and together support government's effort in educational provision. This why the 2013 revised edition of the national education policy guaranteed stakeholders participation in education with a view to eliminate overlaps, sustain and achieve synergy.

\subsubsection{Attending PTA meetings}

Attending PTA meetings is one of the important roles of education stakeholders especially parents and the teachers as stated by the interviewees:

- "Parents are supposed to be conscious of the education of their children. One way to do this is through attending the Parent Teachers' Association's (PTA) meetings and by supporting the school based on their ability so as to ensure educational development".

- "As a parent I am an automatic member of the parent teachers association (PTA) and I regularly attend the PTA meeting which is organized from time to time. However, our views on issues discussed at those meetings are highly respected by the school administration. This gives a room for curtailing the challenges that the school is facing".

- "I am in support of the fact that parents should always attend the parent's teacher's association's meetings. This is because there is exchange and sharing of ideas in such meetings between the parents and teachers on the challenges of education and how to harness the potentials of the children".

The relevance of stakeholders in policy implementation could also be felt according to the research participants through attending PTA meetings. Kamba (2010) and Brussels (2011) observed that involving stakeholders such as the parents in the management of school's affairs helps in improving the quality of the educational system. Also, inability to actively involve them adversely leads to failure of the school's management system (Olatunji, 2012; Olaleye, 2013; Azeem, 2010; Ayeni (2012). It is therefore, imperative that parents and teachers as stakeholders in education should be active in attending such meetings so as to ensure effective implementation.

\subsubsection{Provision of fund by the Government:}

Adequate disbursement and judicious utilization of educational funds is key to successful implementation of educational policies as highlighted by the interviewees:

- "There is the need for adequate educational funding as the strength of countries the world over depends on the quality of the education system which also depends on the proportion of funds injected into the education sector". 


\section{Macrothink}

- "There is the need on the part of the government to provide sufficient funding for the purpose of training and re-training of teachers and in making available the necessary facilities including furniture as well as creating conducive atmospheric condition for both learners (students) and disseminators of knowledge (teachers)".

- "Government should collaborate with private organizations and individuals interested in investing in education for quality education to be improved as the responsibility of education financing is too much on the government".

Making funds available is one of the significant roles of stakeholders especially the government in ensuring effective implementation as noted by the research participants. This is due to the fact that the strength of a nation largely depends on the educational level of its citizens which is guaranteed when adequate funds are provided in the sector (Ololube et al., 2012). Despite the fact that adequate provision of financial resources is necessary in attaining quality education (Earnest, 2011; Adeyemi, 2011; Oseni, 2012; Ejiogu et al., 2013; Greg \& Agboro, 2014), in the Nigerian context for instance, it was identified that the amount allocated to education is grossly inadequate (Adeyemi, 2011; Sofoluwe, 2012; Peter \& Isaac, 2013), and this is the reason why the sector was unable to deliver over the years. Governments should therefore, make sure that adequate funds are allocated to the sector so that the policies could be effectively implemented.

\subsection{Supporting the School}

One of the relevance of stakeholders in education policy implementation is "Supporting the School". As identified by the research participants and displayed in figure 2, supporting the school takes the form of provision of necessary materials, sincerity and honesty in discharging responsibilities, employing quality teachers as well as training and re-training of teachers.

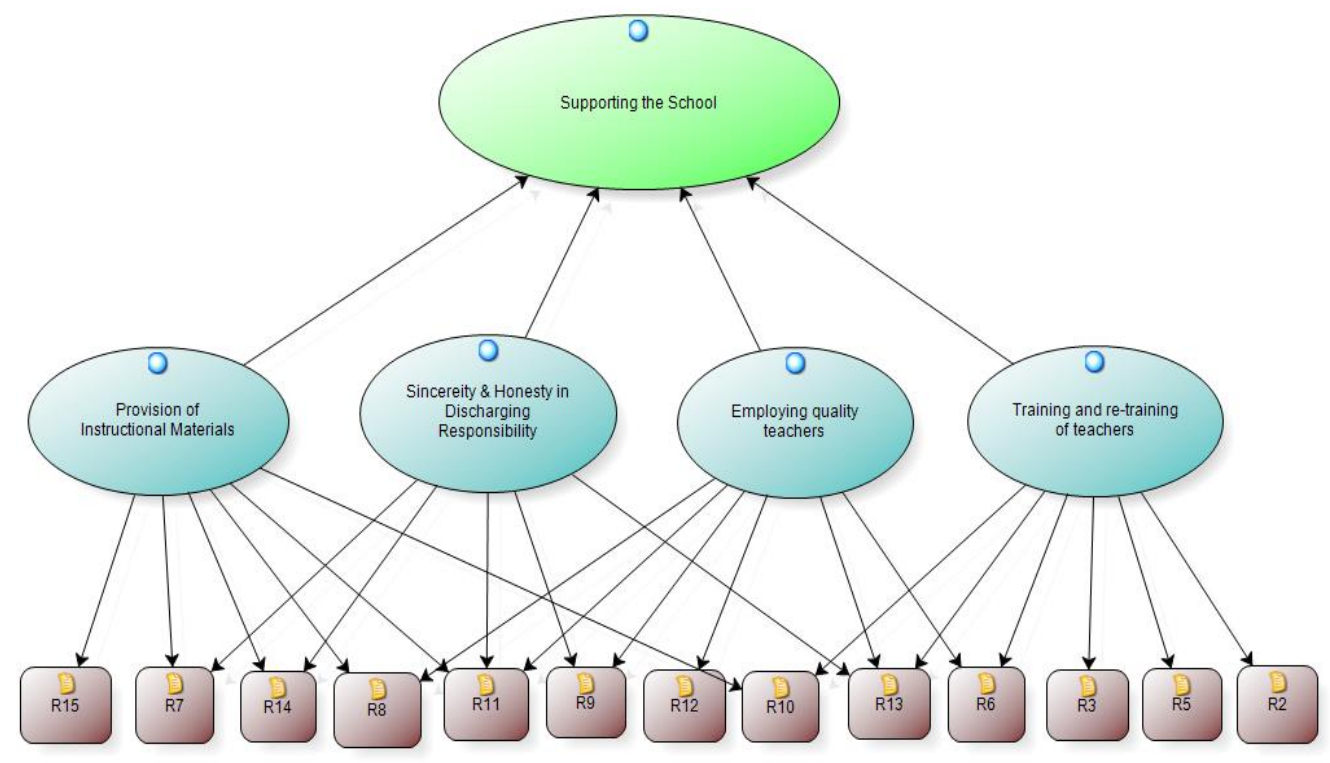

Figure 2. Supporting the school 


\subsubsection{Provision of Instructional materials:}

It was identified by the research participants that sufficient instructional materials are capable of enabling effective teaching. However, as noted by Geoffrey (2013) when teachers teach as stipulated in the curriculum, they are indirectly executing education policies. The research participants stated that:

- "The need for the provision of the necessary materials required in schools by the government is imperative particularly in this era of information technology (IT). Computers and other internet facilities need to be supplied and adequately taking care of. This will enable students to obtain IT knowledge".

- "The required support services including infrastructure, facilities and other necessary equipment and working tools should be adequately provided in schools, as this is capable of enhancing the quality of teaching towards quality output".

- "Government should also provide schools with the needed resources (human and material). Government should stop building schools without adequate provision of the required human and material resources. This is because without the required resources, ensuring quality education will be difficult or almost impossible".

The views support the views of Ekundayo (2010) and Olaniyan and Damilola (2013) who stressed the relevance of adequate instructional materials for effective teaching and learning. However, as noted by the authors in the nigerian context the instructionals are either lacking in derelict conditions. The participants therefore, call on the government to as a matter of utmost importance make all the required instructional materials available in schools especially in this era of technology.

\subsubsection{Honesty and sincerity in discharging responsibilities:}

Honesty and sincerity in discharging responsibilities are fundamental towards effective implementation of education policies as identified by the research participants:

- "It is imperative for the government and its officials to be truthful and sincere in carrying out their duties and responsibilities particularly with respect to the provision of instructional materials. Care should be taken in making supplies so that quality materials, equipment and facilities are supplied".

- "In order to ensure successful implementation towards quality output, it is imperative that all stakeholders should play their roles sincerely in conformity with the established laws".

- "I am of the view that government personnel especially in the ministry as well as the school administrators should be honest. If for instance during teachers recruitment exercise it was found out that there are unqualified teachers, they should not be employed. But what is going on at present is very alarming where teachers are not employed based on merit while some are not even interviewed but they get the job due to their connections". 
Honesty and sincerity denotes doing things properly in line with the prescribed laws. It includes faithfulness and acting according to the ethics of the job. This is immensely useful as it helps in minimizing corruption and other unwanted behaviors that leads to breach of the ethics of the job. Honesty and sincerity leads to effectiveness and efficiency in service delivery, and also promotes accountability by holding those responsible to account for their actions and also improves the quality of the services provided (Bhuyan et al., 2010).

\subsubsection{Employing quality teachers}

Most of the research participants indicated that employing quality teachers greatly help in the implementation of education policies:

- "Qualified professional teachers should be employed because quality education is only guaranteed when there are qualified and professional teachers".

- "In my view to effectively implement education policies, government should make sure that it appoints professional teachers those with the zeal and interest of performing on the job".

- "To have quality students, there must be qualified teachers. This is because with unqualified teachers, quality graduates will not be produced. There is therefore, the need on the part of government to make sure that only qualified teachers are employed. Not only this, government should also ensure that adequate materials are supplied to teachers as well as incentives in order to motivate them towards quality performance".

According to the interviewees most of the teachers teaching in most Nigerian secondary schools are not qualified. Akpan (2012) pointed out that teachers in most of the Nigerian schools are not qualified; and some of them are employed not based on merit or competence (Yaro et al., 2015). This is part of the reasons why low quality education still persists in Nigeria. According to them teachers are the nation builders, and the strength of a country's educational system depends largely on the quality of its teachers. Chong (2014) pointed out that in order to have quality education, there must be competent teachers. The need to employ quality teachers is therefore necessary for the fact that teachers are fundamental in education policy implementation and pillars in ensuring student's academic achievement (Sacilotto, 2013; Brans ford et al., 2005).

\subsubsection{Training and Re-training of teachers:}

One of the relevance or roles of stakeholders in policy implementation especially the government as employers of teachers is to make sure that teachers receive training from time to time. The research participants said:

- "It is often said that no educational system can rise above the level of the teachers' quality. There is the need therefore to make sure that teachers are given effective and efficient training from time to time. In other words, there should be constant training and re-training of the teachers as well as proper supervision". 
- "The teachers need to be trained and re-trained on a continuous basis for them to acquire additional and sufficient expertise and knowledge which will assist them in the teaching and learning process".

- "I would like the government to understand the benefits of training and re-training of teachers especially now that we are in era of innovations and skills. Our teachers need to upgrade to the present status of technology and developments. We have to adapt to the dynamic nature of the changing world to effectively implement the education policies towards better educational output".

Training and re-training is an avenue of making the teachers acquire extra skills and knowledge and this makes them well-informed on current development in the teaching profession. As noted by Geoffrey (2013), Menken and Garcia (2010), and Ricento and Honberger (1996), teachers are very crucial in the implementation of education policies. Teachers should therefore, be constantly trained and re-trained in order for them to get extra knowledge that will assist them towards effective implementation of the education policies.

\section{Conclusion/Recommendations}

As indicated under the analysis and discussion section, stakeholders have great relevance in the implementation of education policies. These relevance or roles include supporting the school and total commitment in education provision. Considering the importance of stakeholders in enhancing effective implementation, it is recommended that government should critically study the findings and focus on the grey areas that need to be rectified urgently. As a matter of utmost importance, the government should as well allow stakeholders full participation in education provision. In other words, government should collaborate with relevant stakeholders in the provision of education especially those stakeholders that are outside the government circle including the community and the NGO's. Government should also strengthen its bureaucratic capacities and should make sure that only competent personnel are employed to oversee the affairs of education. In addition to this, the personnel should be motivated through incentives as this will distract them from corrupt practices that are bound to affect effective implementation. If this is done, there is every likelihood that proper implementation will be ensured which is expected to lead to attainment of the final output (i.e. the goal of ensuring quality education).

\section{References}

Adebayo, F. A. (2013). Stakeholders perception of teacher's integrity in elementary schools in Nigeria. Literacy Information and Computer Education Journal, 4(4), 1214-1219.

Adeyemi, T. (2011). Financing education in Nigeria: An analytical review. American Journal of Social and Management Sciences, 2(3), 295-303. DOI: 10.5251/ajsms.2011.2.3.295.303

Adler, P. A., \& Adler, P. (2011). The tender cut: Inside the hidden world of Self-Injury. New York: New York University Press.

Ajaegby, F. O., \& Eze, E. (2010). Public policy making and analysis. Enugu: Spring Time Press. 
Akpan, E. O. (2012). Investment in education: a panacea for national economic vibrancy. International Journal of Research in Management, Economics and Commerce, 2(10), 243-254.

Audu, R. I., Umar, Y., \& Idris, A. M. (2013). Facilities provision and maintenance: necessity for effective teaching and learning in technical vocation. IOSR Journal of Research Methods in Education, 3(1), 28-32.

Ayeni, A. J. (2012). Improving school and community partnership for sustainable quality assurance in secondary schools in Nigeria. International Journal of Research Studies in Education, 1(2), 95-102. http://dx.doi.org/10.5861/ijrse.2012.v1i2.49

Ayeni, A. J. (2014) Principals and parents partnership for sustainable quality assurance in Nigerian secondary schools. 4th international conference on education research and innovation. IPEDR vol. 81, IACSIT Press, Singapore. DOI: 10.7763/IPEDR.2014.V81.23.

Azeem, V. (2010). An overview of the African education watch Ghana report. Retrieved from: http://www.tighana.org.

Bateye, O. R., \& Ogunyemi, J. O. (2015). The challenge of implementing the language education policy in Nigeria. Journal of Educational Research in Natural and Social Sciences, 1(1), 182-190.

Bhuyan, A., Jorgensen, A., \& Sharma, S. (2010). Taking the pulse of policy: The policy implementation assessment tool. Washington, DC: Future group, health policy initiative, task order 1.

Brans ford, J., Darling-Hammond, L. \& Le Page, P. (2005). Introduction, in Darling-Hammond, L. and brans ford, J. (Eds), Preparing teachers for a changing world: What teachers should learn and be able to do. (pp. 1-39). Jossey-Bass: San Francisco, CA.

Brooks, S. (1998). Public policy in Canada: An introduction (3rd ed.). Toronto: Oxford University press.

Brugha, R. \& Varvasovszky, Z. (2000). Stakeholder analysis: A review. Health Policy and Planning, 15(3), 239-246. DOI: https://doi.org/10.1093/heapol/15.3.239

Brussels, M. D. (2011). Report of the conference of the European network on education councils (EUNEC) on participation and stakeholder involvement in education policy making. Retrieved from: http://www.eunec.eu.

Charles, M. O., \& Sunday, I. E. (2014). Partnering for education finance in Nigeria. Journal of Studies in Education, 4(1), 180-189. DOI: http://dx.doi.org/10.5296/jse.v4i1.4977

Chinelo, O. D. (2011). Falling standard of Nigeria Education: Traceable to proper skills acquisition in schools? Educational Research, 2(1), 803-808.

Chong, S. (2014). Academic quality management in teacher education: a Singapore perspective. Quality Assurance in Education, 22(1), 53-64. DOI: http://dx.doi.org/10.1108/QAE-05-2012-0023 
Clase, P., Kok, J., \& Van der, M. M. (2007). Tension between school governing bodies and education authorities in South Africa and proposed resolutions. South Africa Journal of Education, 27(2), 243-263.

Creswell, J. W., Vicki. L., \& Clark, P. (2007). Designing and conducting mix methods research. Thousand Oaks, CA: Sage Publications.

Crosby, B. Stakeholder analysis: A vital tool for strategic managers. Washington, DC, USAID.

Denscombe, M. (2003). The good research guide for small scale social research (2nd ed.). Buckingham's open university press.

Dorathy, O. (2011). Assessment of the implementation of secondary school skill-based curriculum to youth empowerment in Nigeria. Edo Journal of Counseling, 4(1 \& 2), 75-91.

Ejiogu, U., Okezie, A. I., \& Chinedu, N. (2013). Causal relationship between Nigerian government budget allocation to the education sector and economic growth. Discourse Journal of Educational Research, 1(8), 54-64.

Ekundayo, H. T. (2010). Administering secondary schools in Nigeria for quality output in the 21st Century: The principal's challenge. European Journal of Educational Studies, 2(3), 187-192.

Ernest, S. O. (2011). Government spending on education, economic growth and long waves in a CGE micro-simulation analysis: The case of Nigeria. British Journal of Economics, Finance and Management Sciences, 1(2), 74-87.

Freeman, R. E. (1984). Strategic management: A stakeholder approach. Boston, MA: Pitman Publishing.

Geurtz, C. \& Ted, V. W. (2010). Making citizen participation work: The challenging search for new forms of local democracy in the Netherlands. Local Government Studies, 36(4), 531-549.

Gibson, W. (2006). Theoretical issues in thematic analysis. Thousand Oaks, CA: Sage publications.

Godfrey, T. (2013). How should quality of education be re-defined for education achievement in Tanzania? What are stakeholder's opinions? Journal of International Education and Leadership, 3(1), 1-7.

Greg, E. E., \& Agboro, D. E. (2014). The determinants of public expenditure on educational infrastructural facilities and economic growth in Nigeria. E3 Journal of Business Management and Economics, 5(6), 152-161.

Helle, D., Letshego, M., \& Marinda, W. (2011). Perception of knowledge of rules and respect among educators: Teachers as an indicator of integrity. Retrieved from: http://www.un.org/tisda South Africa 


\section{Macrothink}

Honberger, N. H., \& Ricento, T. (1996), Unfeeling the onion: Language Planning and policy and the ELT professional. TESOL Quarterly, 30, 401-426.

Innocent, O. (2013). Implementing vocational and technical education programs in south-south Nigeria: A case of Rivers state. International Journal of Scientific Research in Education, 6(2), 128-148.

James, C., Brammer, S., Connolly, M., Fertig, M., James, J. \& Jones, J. (2010). The hidden givers: a study of school governing bodies in England. Retrieved from: http:www.cfbt.com/evidenceforeducation

Kamba, K. (2010). Education development in southern Sudan: A study of community participation and democratic leadership in two primary schools in central equatorial state, southern Sudan, Oslo University College: Faculty of Education and International Studies.

Kraft, M. \& Furlong, S. (2007). Public policy: Politics and analysis. Washington: CQ Press.

Kufi, E. F. (2013). The role of different stakeholders in Ethiopia in the improvement of educational quality. International Journal of Research Studies in Education, 2(1), 11-24. DOI: 10.5861/ijrse.2012.51

Lin, R. (2010). The role of parent-teachers associations. Retrieved from: http://www.ehow.co.uk.

Mandina, S., \& Chiheve, H. (2013). Quality and accountability in education: what say the school heads? Educational Research International, 2(2), 165-173.

Mason, R. O. \& Mitroff, I. I. (1981). Challenging strategic planning assumptions: Theory, cases, and techniques. New York: John Wiley \& Sons.

Mazmanian, D. A., \& Sabatier, P. A. (1983). Implementation and public policy. Glenview, III.: Scott, Foresman.

McNamara, C. (2009). General guidelines for conducting interviews. Retrieved January 11, 2010, from: http://managementhelp.org/evaluation/interview.htm

Menken, K. \& Garcia, O. (2010). Negotiating language policies in schools: Educators as policy makers. New York, N.Y.

Miles, M., \& Huberman, M. (1994). Qualitative data analysis: an expanded source book. London: Berverly Hills.

Mualuko, N. J. Mukasa, S. A. \& Judy, A. S. K. (2009). Improving decision making in schools through teacher participation. Educational Research and Review, 4(8), 391-397.

Odufowokan, B. A. (2011). Organization and management problems confronting re-designing teaching and learning in Nigerian schools in the globalization era. Journal of Management and Strategy, 2(2), 78-86. DOI:10.5430/jms.v2n2p78 
Olaleye, F. O. (2013). Principal's organizational management and student's academic achievement in secondary schools of Ekiti state, Nigeria. Singaporean Journal of Business, Economics and Management Studies, 2(2), 76-84.

Olaniyan, O. D., \& Anthony, K. I. (2013). Effect of inadequate school plant on academic performance of Nigerian secondary school's students. International Journal of Humanities and Management Sciences, 1(3), 198-200.

Olatunji, S. A. (2012). Appraisal of school plant adequacy for primary education in Ayedaade local government area of Osun state, Nigeria. Asian Journal of Social Sciences and Humanities, 1(4), 206-211.

Ololube, N. P., Amaele, S., Kpolovie, J. P., Onyekwere, L. A., \& Elechi, G. E. (2012). Quality higher education for improved knowledge essential for national and regional development. International Journal of Education, Economics and Development, 3(2), 179-204.

Oseni, M. (2012). Adequacy of budgetary allocation to educational institutions in Nigeria. Pakistan Journal of Business and Economic Review, 3(1), 143-157.

Paine, S., \& McCann, R. (2009). Engaging stakeholders. Sustainability Series, 6, 1-16.

Paudel, N. R. (2009). A Critical account of policy implementation theories: status and reconsideration. Nepalese Journal of Public Policy and Governance, 25(2), 36-54.

Peter, J. O. \& Isaac, E. (2013). Adequacy and inadequacy of education funding in Nigeria. Universal Journal of Education and General Studies, 2(8), 239-254.

Peters, B. G. (2014). Implementation structures as institutions. Public Policy and Administration, 29(2), 131-144. DOI: 10.1177/0952076713517733

Pressman, J., \& Wildavsky, A. (1973). Implementation: How Great Expectations in Washington are dashed in Oakland, Berkeley: University of California Press.

Sacilotto-Vasylenko, M. (2013). Bologna process and initial teacher education reform in France, in Motoko Akiba (ed.) Teacher Reforms Around the World: Implementations and Outcomes. International Perspectives on Education and Society, 19, 3-24. DOI: 10.1108/S1479-3679(2013)0000019006

Schlechty, P. C. (2001). Shaking up the schoolhouse: How to support and sustain educational innovation, San Francisco, Jossey-Bass.

Sofoluwe, A. O. (2012). Innovative strategies for financial management in Nigerian public secondary schools. US-China Education Review, 2, 224-235.

Stefl, M. E. \& Tucker, S. L. (1994). Applying stakeholder analysis to health care administration education. Journal of Health Administration Education, 12, 119-44.

Strauss, A., \& Corbin, J. (1990). Basics of qualitative research: Grounded theory procedures and techniques. Newbury Park, CA: Sage Publications. 


\section{Macrothink}

Journal of Public Management Research

ISSN 2377-3294

2017, Vol. 3, No. 1

Takyi, H., Emmanuel, K. A. \& Yussif, K. A. (2013). The level of stakeholder's participation in the district education strategic planning towards quality basic education: The case of salaga town council of Ghana. International Journal of Humanities and Social Science, 3(14), 95-102.

Torenvlied, R. \& Akkerman, A. (2004). Theory of "soft" policy implementation in multilevel systems with an application to social partnership in the Netherlands. Acta Politica, 39(1), 31-58. DOI: 10.1057/palgrave.ap.5500046

Walt, G. (1994). Can interest groups influence government policy? Health Policy: An introduction to process and power, Zed Publications, London.

Yaro, I., Rozita, A., \& Dani, S. (2015). Education stakeholder's constraints in policy decision for effective policy implementation in Nigeria. British Journal of Education, Society and Behavioral Science, 14(1), 1-12.

\section{Copyright Disclaimer}

Copyright for this article is retained by the author(s), with first publication rights granted to the journal.

This is an open-access article distributed under the terms and conditions of the Creative Commons Attribution license (http://creativecommons.org/licenses/by/3.0/). 